\title{
Thai Purple Sweet Potato Flours: Characteristic and Application on Puffed Starch-Based Snacks
}

\author{
Naraporn Phomkaivon ${ }^{1}$, Vipa Surojanametakul ${ }^{1}$, Prajongwate Satmalee ${ }^{1}$, Narin Poolperm ${ }^{2} \&$ Narong Dangpium ${ }^{3}$ \\ ${ }^{1}$ Institute of Food Research and Product Development, Kasetsart University, Bangkok, Thailand \\ ${ }^{2}$ Office of Agricultural Research and Development Region 2, Phitsanulok, Thailand \\ ${ }^{3}$ Phichit Agricultural Development and Research Center, Phichit, Thailand \\ Correspondence: Naraporn Phomkaivon, Institute of Food Research and Product Development, Kasetsart \\ University, Bangkok, 10900, Thailand. Tel: 662-942-862-935. E-mail: ifrnpph@ku.ac.th
}

\author{
Received: July 16, $2018 \quad$ Accepted: August 22, $2018 \quad$ Online Published: October 15, 2018 \\ doi:10.5539/jas.v10n11p171 URL: https://doi.org/10.5539/jas.v10n11p171
}

\begin{abstract}
Characteristics and properties of 4 Thai purple sweet potato flours, Maejo 343, Phichit 65-3, Phichit 290-9 and Torperk were determined in terms of native and pre-gelatinized flours. Color, physicochemical properties and antioxidant activity of native and pre-gelatinized flours depend on their varieties. All native flours showed low redness $\left(a^{*}\right)$ and blueness $\left(-b^{*}\right)$ values but high pasting properties. Pre-gelatinized flours had a unique purple color and high antioxidant activity. Flours produced by Phichit 65-3 showed a deep intense purple color, high anthocyanins and good antioxidant activity. Both native and pre-gelatinized Phichit 65-3 flours were used as the main raw materials of air-puffed pre-gelatinized flours with different ratios at $10 \%, 30 \%$ and $50 \%$. Increasing the content of pre-gelatinized flours improved color, expansion and antioxidant activity of snacks. Low hardness $(9.55-11.65 \mathrm{~kg})$ was presented in all snacks prepared from sweet potato flours. Purple sweet potato snacks prepared from $50 \%$ pre-gelatinized flour had good appearance, light texture, high anthocyanins and high antioxidant activity. Results showed that Thai purple sweet potato flours can be used to produce healthy snacks with improved appearance and texture. They also have potential as sources of natural colorants and antioxidants in food products.
\end{abstract}

Keywords: sweet potato, physicochemical properties, antioxidant activity, snack, microstructure

\section{Introduction}

Starch-based snacks are well-known global food products with a unique appearance, taste and texture. Normally, starch-based snacks are puffed to create a porous structure and crispy texture (Mariotti et al., 2006; Nemś et al., 2015). Expansion of the puffed snacks depends on several factors such as raw materials used, amylose-amylopectin ratio, degree of gelatinization, moisture content and puffing methods (Norton et al., 2011; Wang et al., 2012; Jiamjariyatam et al., 2017). Starch-based snacks have been traditionally puffed by deep-frying; however, high oil content in these products can cause health problems and short shelf life (Chen et al., 2016). Air-puffing or baking were applied to snacks for health-conscious consumers for convenient operation. Addition of dietary fiber, protein from plant sources and natural antioxidants were also used to improve the nutritional and health benefits of the snacks (Nath \& Chattopadhyay, 2007; Reddy et al., 2014; Nemś et al., 2015). Moreover, root and tuber crops such as potato, sweet potato, yam, taro and beet root were selected to develop the appearance and nutritional properties of snacks from corn and black gram flour (Reddy et al., 2014). Snacks produced with colored potato flour had 2-3 times higher antioxidant activity, high content of polyphenols, attractive color and better expansion. Losses of anthocyanins during snack processing depended on potato varieties (Nemś et al., 2015). The utilization of starchy tubers and air-puffing has become an alternative method of producing healthy snacks with good expansion, increasing acceptance and source of phytochemicals.

Purple sweet potatoes (Ipomoea batatas L. Lam) are starchy tubers which have good nutritional value and positive health benefits as excellent sources of carbohydrate, fiber, vitamins, minerals and phytochemical compounds (Van Hal, 2000; Teow et al., 2007). They show an intense purple color due to the accumulation of acylated anthocyanins as peonidin-based and cyanidin-based which provide various biological functions such as free radical scavenging, anticarcinogenic activity and antihypertensive effects (Oki et al., 2002; Yang \& Gadi, 
2008). Purple sweet potato anthocyanins can be used as natural food-safe edible colorants (Suda et al., 2003; Terahare et al., 2004). Sweet potatoes have great potential to contribute to the human diet and food production as starch, bakery and snacks. Moreover, they can be used as functional ingredients in various food products, especially in flour form. Flour production is a common technique for root preservation with many advantages including longer shelf life, ready usage and easy delivery, thus increasing the economic value of sweet potatoes.

In recent years, purple sweet potatoes have been widely grown in several areas of Thailand. The four selected varieties had outstanding characteristics. Phichit 290-2 is the base for new purple-fleshed breeding while Torperk is widely consumed in Thai markets. The two new breeding varieties, Maejo 343 and Phichit 65-3, are fast-growing and have higher productivity. Moreover, Phichit 65-3 variety has a noticeable deep purple color. The properties of Thai purple sweet potato flours are sparsely reported in the literature; however, the characteristics and physicochemical properties of flour-based plants play important roles in the commercial application of starch in various food product categories.

This study investigated and compared characteristics, physicochemical properties and antioxidant activity of native and pre-gelatinized Thai purple sweet potato flours. Applications of purple sweet potato flour on air-puffed snacks were formulated from selected varieties that exhibited deep intense purple color, high anthocyanin content and high antioxidant activity. Physical properties of purple sweet potato snacks as expansion ratio, hardness, crispiness, macrostructure and antioxidant activity were observed.

\section{Method}

\subsection{Samples}

Four varieties of purple sweet potato (Maejo 343, Phichit 65-3, Phichit 290-9 and Torperk) were provided by the Agriculture Development and Research Center, Phichit, Thailand. Fresh roots (50 kg per each variety) were stored at $10{ }^{\circ} \mathrm{C}$ prior to use (Figure 1).

\subsection{Flour Preparation}

\subsubsection{Native Flour}

Purple sweet potato flours were prepared following the method of Aina et al. (2009) with some modifications. Briefly, all the roots were cleaned, hand-peeled and cut into $2 \mathrm{~mm}$ thick slices using a food processor (CombiMax 600, Braun, Hungary). The thin slices were dried in a hot air oven at $50{ }^{\circ} \mathrm{C}$ (Memmert, Germany) until the moisture content was below $12 \%$. They were then ground and sieved through a 100 mesh screen. The native flours were stored in polyethylene bags at $4{ }^{\circ} \mathrm{C}$ until required for use.

\subsubsection{Pre-gelatinized Flour}

The peeled purple sweet potatoes were cut into $4 \mathrm{~cm}$ pieces crosswise, then steamed at $100{ }^{\circ} \mathrm{C}$ for $30 \mathrm{~min}$ (Tefal steam cooker, France), cooled and cut into $2 \mathrm{~mm}$ thick slices with a sharp knife. The steamed samples were dried in a hot air oven at $50{ }^{\circ} \mathrm{C}$ (Memmert, Germany) until the moisture content was below $12 \%$, then ground to a powder using a laboratory grinder and sieved through a 100 mesh screen. The pre-gelatinized flours were stored in polyethylene bags at $4{ }^{\circ} \mathrm{C}$ until required for use.

\subsection{Flour Characteristics}

\subsubsection{Chemical Compositions and Color Measurement}

Purple sweet potato flours were analyzed for proximate composition (AOAC, 2000). Color attributes as Hunter $L^{*}, a^{*}, b^{*}$ values (Lightness, redness and yellowness) were determined using a Datacolor Spectrophotometer Spectraflash SF 600 plus (Datacolor International, USA). 


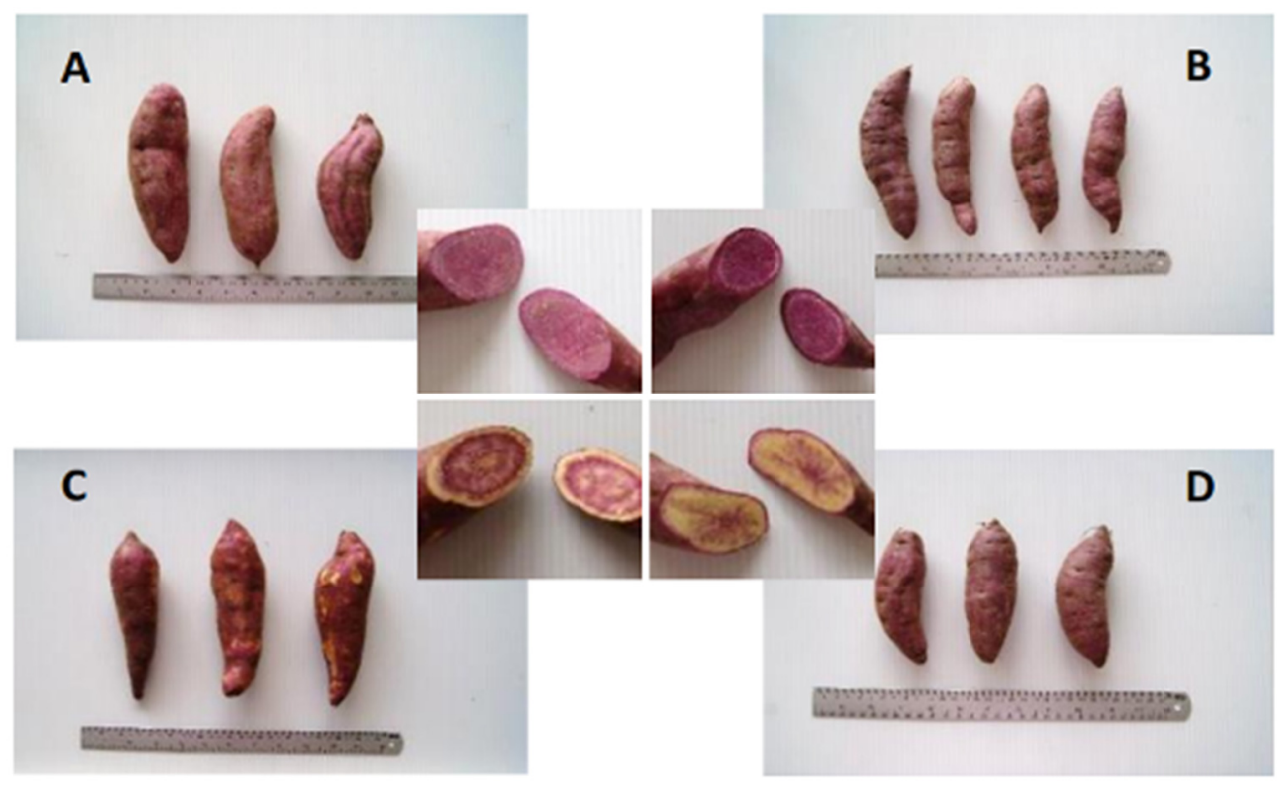

Figure 1. Thai purple sweet potatoes (A) Maejo 343, (B) Phichit 65-3, (C) Phichit 290-9 and (D) Torperk

\subsubsection{Flour Hydration Properties}

The water holding capacity (WHC), swelling volume (SV) and water binding capacity (WBC) of purple sweet potato flours were evaluated following the method reported by Cornejo and Rosell (2015). A sample of $1 \mathrm{~g} \mathrm{(db)}$ was mixed with distilled water $(10 \mathrm{ml})$ at room temperature for $24 \mathrm{~h}$. The supernatant was carefully removed and WHC was calculated by the weight of sediment after removal supernatant per gram of solid. SV was determined by the total volume of swollen sample after $24 \mathrm{~h}$ at room temperature per gram of sample. WBC expressed the amount of water retained by the sample under low-speed centrifugation. Briefly, the mixture of sample $(1 \mathrm{~g} \mathrm{db})$ and distilled water $(10 \mathrm{ml})$ was centrifuged at $3,000 \times \mathrm{g}$ for $10 \mathrm{~min}$. WBC was described by weight of sediment after centrifugation per gram of solid. WHC, SV and WBC were calculated by Equations (1-3):

$$
\begin{gathered}
\text { WHC }(\mathrm{g} / \mathrm{g})=\text { Weight of sediment after draining supernatant/Sample weight } \\
\mathrm{SV}(\mathrm{ml} / \mathrm{g})=\text { Total volume of swollen sample/Sample weight } \\
\text { WBC }(\mathrm{g} / \mathrm{g})=\text { Weight of sediment after centrifugation/Sample weight }
\end{gathered}
$$

\subsubsection{Flour Gelling Behavior}

The purple sweet potato flours were measured for water absorption index (WAI), water solubility index (WSI) and swelling power (SP) according to the method of Cornejo and Rosell (2015) with some modifications. Flour sample $(1 \mathrm{~g} \mathrm{db})$ was suspended in $10 \mathrm{ml}$ distilled water and cooked at $90^{\circ} \mathrm{C}$ for $30 \mathrm{~min}$ in a water bath. After the cooked paste was cooled, it was centrifuged at $3,000 \times \mathrm{g}$ for $10 \mathrm{~min}$. The supernatant was decanted into an evaporation dish and the sediment was weighed. Dry solids of supernatant were determined. WAI, WSI and SP were calculated by Equations (4-6):

$$
\text { WAI }(\mathrm{g} / \mathrm{g})=\text { Weight of sediment/Sample weight }
$$

WSI $(\mathrm{g} / \mathrm{g})=$ Weight of dissolved solids in supernatant/Sample weight

$$
\mathrm{SP}(\mathrm{g} / \mathrm{g})=\text { Weight of sediment/Weight of dissolved solids in supernatant }
$$

For the determination of oil absorption capacity (OAC) the modified method of Fiorda et al. (2015) was applied. Flour sample $(1 \mathrm{~g} \mathrm{db})$ was mixed with soya oil $(10 \mathrm{ml})$ and centrifuged at $3,000 \times \mathrm{g}$ for $10 \mathrm{~min}$. The sediment was weighed after draining soya oil and OAC was calculated by Equation (7):

$$
\text { OAC }(\mathrm{g} / \mathrm{g})=\text { Weight of sediment after draining oil/Sample weight }
$$

\subsubsection{Pasting Properties}

Pasting properties of purple sweet potato flours were evaluated using a Rapid Visco Analyzer (RVA Super 3, Newport Scientific, Australia). Flour suspension was prepared with $3 \mathrm{~g}$ samples in $25 \mathrm{ml}$ water at $12 \%$ moisture content. Heating and cooling were programmed, with the sample held at $50{ }^{\circ} \mathrm{C}$ for $1 \mathrm{~min}$, heated to $95{ }^{\circ} \mathrm{C}$ at 
$6{ }^{\circ} \mathrm{C} / \mathrm{min}$ and held for $5 \mathrm{~min}$, then cooled to $50{ }^{\circ} \mathrm{C}$ in $2 \mathrm{~min}$. Peak viscosity, trough viscosity, final viscosity, breakdown, and setback viscosity were recorded.

\subsubsection{Antioxidant Activity}

Purple sweet potato flours were extracted using modified methods of Bridgers et al. (2010). Briefly, a mixture of $10 \mathrm{~g}$ flour sample and $100 \mathrm{ml} \mathrm{80 \%} \mathrm{ethanol} \mathrm{(ratio} \mathrm{1:10)} \mathrm{was} \mathrm{placed} \mathrm{in} \mathrm{a} \mathrm{shaking} \mathrm{water} \mathrm{bath} \mathrm{at} 80{ }^{\circ} \mathrm{C}$ for $2 \mathrm{~h}$ and then filtered through Whatman No.1 filter paper. Extracts were kept at $-20{ }^{\circ} \mathrm{C}$ until required for analysis. Total phenolic contents (TPC) of extracts were determined following the Folin-Ciocalteu method described by Singleton et al. (1999) and TPC was calculated and expressed as mg gallic acid equivalent (GAE) per g db. Total anthocyanin content (TAC) was determined following the procedure of Huang et al. (2006) and TAC was calculated from Equation (8):

$$
\mathrm{TAC}=\mathrm{A} \times \mathrm{M}_{\mathrm{w}} \times \mathrm{DF} \times 100 /(\varepsilon \times \mathrm{W})
$$

Where, $\mathrm{A}=(\mathrm{A} 520-\mathrm{A} 700)_{\mathrm{pH} 1.0}-(\mathrm{A} 520-\mathrm{A} 700)_{\mathrm{pH} 4.5}, \mathrm{M}_{\mathrm{w}}=$ molecular weight of cyanidin-3-glucoside (449.2), $\mathrm{DF}=$ dilution factor, $\varepsilon=$ molar absorptivity $(26,900)$, and $\mathrm{W}=$ sample weight $(\mathrm{g})$.

Antioxidant activities of extract were investigated by 3 different assays. The DPPH free radical scavenging activity assay followed a modified method described by Brand-Williams et al. (1995). Briefly, $1 \mathrm{ml}$ of extract was mixed with $3 \mathrm{ml}$ of $0.2 \mathrm{mM}$ DPPH. After 30 min of incubation in the dark, the absorbance was measured at $517 \mathrm{~nm}$. The \%inhibition was calculated using the equation:

$$
\text { Inhibition }(\%)=\left[1-\left(\mathrm{A}_{\text {sample }} / \mathrm{A}_{\text {blank }}\right) \times 100\right]
$$

Trolox equivalent antioxidant capacity (TEAC) assay was performed as described by Zhou and Yu (2004) and ferric-reducing antioxidant power (FRAP) assay was tested according to Benzie and Strain (1999). The calibration curve of Trolox was constructed and antioxidant activities (DPPH, TEAC and FRAP values) were expressed as mg of Trolox equivalent (TE) per $\mathrm{g} \mathrm{db}$.

\subsection{Preparation of Purple Sweet Potato Snacks}

Purple sweet potato snacks were prepared using purple sweet potato flour, composite flour (tapioca, corn and wheat flour) and water at ratio 1:1:1.5 (w/w). Salt at $0.75 \%$ was added and the mixture was kneaded for $15 \mathrm{~min}$. The dough was rolled out to a thickness of $40 \mathrm{~mm}$ and steamed for gelatinization. After cooling, the dough was cut into strips $(40 \times 20 \times 450 \mathrm{~mm})$ and dried at $50{ }^{\circ} \mathrm{C}$ for $1 \mathrm{~h}$. The dough was formulated with 10,30 and $50 \%$ pre-gelatinized flour (w/w). For preparing the control snack, sweet potato flours were replaced by steamed purple sweet potato $(\mathrm{db})$ at the same ratio. All dried dough was puffed in an oven (Healsio AX-1500X, Sharp, Japan) at $230{ }^{\circ} \mathrm{C}$ for 80 seconds. The purple sweet potato snacks were kept in polyethylene bags until required for physical analysis.

\subsection{Physical Properties of Air-Puffed Purple Sweet Potato Snacks}

\subsubsection{Color Measurement}

Surface color of snacks was measured by a Datacolor spectrophotometer Spectraflash SF 600 plus (Datacolor International, USA) and expressed as $L^{*}, a^{*}, b^{*}$ values (Lightness, redness and yellowness).

\subsubsection{Expansion Ratio}

Expansion ratio of snacks was determined using the modified method of Segnini et al. (2004). A ratio of the difference between final volume and initial volume was expressed.

\subsubsection{Bulk Density}

Bulk density of snacks was determined using the sesame seed displacement method described by Sahin and Sumnu (2006). Bulk density ( $p$ ) was calculated as:

$$
\text { Bulk density = Mass of snacks/Volume of snacks }
$$

\subsubsection{Microstructure of Purple Sweet Potato Snacks}

Cross sections of snacks were mounted on a specimen holder and then coated with gold. Fixed specimens were examined using SEM (Jeol JSM-6390, Korea).

\subsubsection{Textural Properties}

Hardness and crispiness were examined on a Texture Analyzer (TA-XT2, Macro stable systems, UK) with 5-blade Kramer shear cell and $5.0 \mathrm{~kg}$ load cell. Hardness value was considered as maximum peak force (kg) and 
crispiness value was determined by linear distance $(\mathrm{kg} \mathrm{s})$. The study was conducted at a distance of $20 \mathrm{~mm}$ with test speed at $2 \mathrm{~mm} / \mathrm{s}$. An average of 15 measurements was reported.

\subsubsection{Antioxidant Activity}

Extraction of snacks followed the same manner as in section 2.3.5 and they were kept at $-20{ }^{\circ} \mathrm{C}$ until required for analysis. Total phenolic content, total anthocyanin content and 3 different antioxidant activity assays in 2.3.5 were applied to snack extracts. Values of TPC, TAC, DPPH, TEAC and FRAP were expressed as previously described.

\subsection{Statistical Analysis}

All experiments were performed in triplicate. Statistical analyses of all data were conducted using one-way ANOVA analysis of variance. Duncan's multiple range test (DMRT) at $p<0.05$ significance was used to estimate differences between the means with SPSS software for Windows (Version 15). Data were also evaluated using Pearson's correlation coefficient to establish the relationship among variables.

\section{Results and Discussion}

\subsection{Flour Characteristics}

Appearance of native and pre-gelatinized purple sweet potato flours prepared from Maejo 343, Phichit 65-3, Phichit 290-9 and Torperk are shown in Figure 2. Moisture content of 4 native flours produced from Thai purple sweet potato ranged from 6.35 to $7.54 \%$. Fat, ash and protein contents ranged at $0.45-0.56 \%, 2.48-4.00 \%$ and 2.61-3.47\%, respectively. Thai sweet potato flours showed fat and protein contents lower than previous studies. Ramesh Yadev et al. (2006) reported 1.0-1.1\%fat and 6.3-6.6\% protein contents of Indian red skin sweet potato flours. Aina et al. (2009) reported fat and protein contents of Caribbean sweet potato flour at $0.2-1.8 \%$ and $2.7-4.4 \%$, respectively. Variations may be due to different sweet potato varieties with diverse preparation and drying processes. Phosphorus, total sugar and amylose content of Thai sweet purple potato flours ranged at 0.175-0.351 g/100 g, 6.06-7.78 g/100 g and 13.83-16.9\%, respectively. Phosphorus and amylose contents of Torperk flours were significantly lower than other varieties. However, there were no significant differences between native and pre-gelatinized flours of each variety (data not shown).

Color attributes were expressed as Hunter values $\left(L^{*}, a^{*}\right.$ and $\left.b^{*}\right)$. Results indicated that both native and pre-gelatinized flours showed significantly different color parameters (Table 1). All pre-gelatinized flours had higher redness $\left(a^{*}\right)$ but lower yellowness $\left(b^{*}\right)$ and lightness $\left(L^{*}\right)$ values than native flours. An increase in $a^{*}$ value after thermal pretreatment was reported in several varieties of Thai purple sweet potato and correlated with the formation of polymeric anthocyanins (Reugmaneepaitoon, 2009; Soison et al., 2014). Among these, both native and pre-gelatinized flours produced from Phichit 65-3 showed an intense purple color with the highest redness $\left(+a^{*}=11.66\right.$ and 15.48 , respectively) and blueness $\left(b^{*}=1.58\right.$ and -6.55 , respectively). These results compared favorably with previous studies (Ruttarattanamongkol et al., 2016). Phichit 65-3 variety is, therefore, a good source for flour production with heat stable purple color.

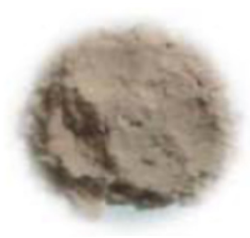

Maejo 343

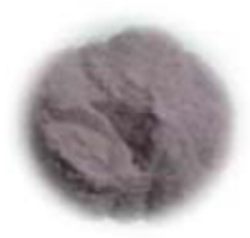

Maejo 343

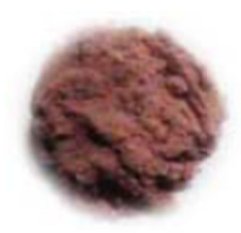

Phichit 65-3

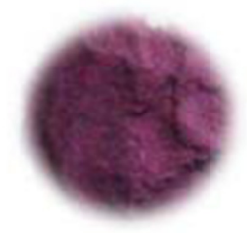

Phichit 65-3

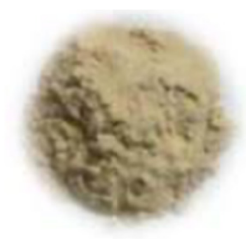

Phichit 290-9

(A)

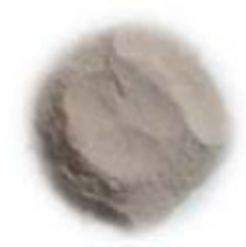

Phichit 290-9

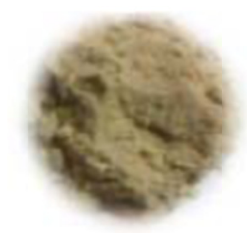

Torperk

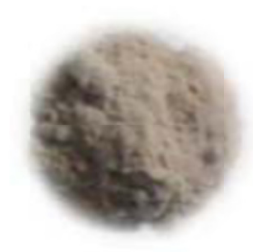

Torperk

(B)

Figure 2. Appearance of Thai purple sweet potato flours. (A) Native Flour And (B) Pre-Gelatinized Flour 
Table 1. Color parameters of Thai purple sweet potato flours

\begin{tabular}{|c|c|c|c|c|}
\hline \multirow{2}{*}{ Flour } & \multirow{2}{*}{ Variety } & \multicolumn{3}{|c|}{ Color value } \\
\hline & & $L^{*}$ & $a^{*}$ & $b^{*}$ \\
\hline \multirow[t]{4}{*}{ Native } & Maejo 343 & $75.44 \pm 0.40^{\mathrm{d}}$ & $7.51 \pm 0.17^{\mathrm{e}}$ & $4.94 \pm 0.08^{\mathrm{e}}$ \\
\hline & Phichit 65-3 & $66.85 \pm 0.24^{\mathrm{b}}$ & $11.66 \pm 0.05^{\mathrm{g}}$ & $1.58 \pm 0.02^{\mathrm{c}}$ \\
\hline & Phichit 290-9 & $79.04 \pm 0.12^{\mathrm{f}}$ & $4.28 \pm 0.02^{\mathrm{a}}$ & $10.90 \pm 0.04^{\mathrm{f}}$ \\
\hline & Torperk & $76.51 \pm 0.26^{\mathrm{e}}$ & $4.84 \pm 0.08^{\mathrm{b}}$ & $12.52 \pm 0.13^{\mathrm{g}}$ \\
\hline \multirow[t]{4}{*}{ Pre-gelatinized } & Maejo 343 & $67.16 \pm 0.30^{\mathrm{b}}$ & $10.21 \pm 0.11^{\mathrm{f}}$ & $-2.47 \pm 0.03^{\mathrm{b}}$ \\
\hline & Phichit $65-3$ & $62.50 \pm 0.44^{\mathrm{a}}$ & $15.48 \pm 0.19^{\mathrm{h}}$ & $-6.55 \pm 0.08^{\mathrm{a}}$ \\
\hline & Phichit 290-9 & $75.61 \pm 0.43^{\mathrm{d}}$ & $6.25 \pm 0.17^{\mathrm{d}}$ & $1.88 \pm 0.07^{\mathrm{d}}$ \\
\hline & Torperk & $74.72 \pm 0.40^{\mathrm{c}}$ & $6.03 \pm 0.15^{\mathrm{c}}$ & $4.88 \pm 0.12^{\mathrm{e}}$ \\
\hline
\end{tabular}

Note. Each value represents mean values \pm standard error.

Color values: $L^{*}, a^{*}$ and $b^{*}$ mean lightness, redness and yellowness, respectively.

${ }^{\mathrm{a}-\mathrm{g}}$ Mean values within the same column with different letters are significantly different at $p<0.05$.

Native and pre-gelatinized sweet potato flours were evaluated for hydration properties as presented in Table 2. The WBC, WHC and SV values of pre-gelatinized flours were 2 times higher than native flours. Highest hydration properties were observed in pre-gelatinized Torperk flours. The WAI and WSI of native Torperk flours were $8.18 \mathrm{~g} / \mathrm{g}$ and $33.53 \mathrm{~g} / \mathrm{g}$, higher than WAI and WSI $(2.57 \mathrm{~g} / \mathrm{g}$ and $16.58 \mathrm{~g} / \mathrm{g})$ reported by Soison et al. (2014). Native flours had higher WAI and SP values than pre-gelatinized flours at $90^{\circ} \mathrm{C}$, while high WSI was presented in pre-gelatinized flour. Soison et al. (2014) reported that pre-gelatinized flour showed 3 times higher WSI than native flour. Swelling behavior of Phichit 290-9 flours gave the lowest WSI and SP values, possibly due to the high fat and protein contents. Oil absorption capacity (OAC) of flours ranged between 2.19 and $2.60 \mathrm{~g} / \mathrm{g}$ with no significant differences $(p<0.05)$ among varieties or types. The oil absorption implied the nonpolar sited of protein or lipid in starch granules (Fiorda et al., 2015). Hydration properties and gelling behavior of flours depended on their characteristic of starch granules. Water-binding capacity constituted the ability of hydrophilic part in starch molecules, water was absorbed in the amorphous zone of the starch and become swollen. The change in small crystallites caused the striping of chains and melting of crystallites. Pre-gelatinized flours showed the high hydration properties due to the structural rearrangement or degradation of starch granules during thermal processing (Neelam et al., 2012). Moreover, the variation in solubility and swelling power could be caused by differing degrees of engagement of the hydroxyl groups, forming hydrogen and covalent bonds between the starch chains (Gunarate \& Hoover, 2002). Results indicated that thermal pre-treatment improved both the hydration properties and gelling behavior of flours of Thai purple sweet potato flours and pre-gelatinized flours showed the cold water-soluble ability.

Table 2. Hydration properties of purple sweet potato flours

\begin{tabular}{lllllllll}
\hline Flour & Variety & WBC & WHC & SV & WAI & WSI & SP & OAC \\
\hline Native & Maejo 343 & $3.25 \pm 0.18^{\mathrm{a}}$ & $3.83 \pm 0.16^{\mathrm{a}}$ & $2.59 \pm 0.16^{\mathrm{a}}$ & $8.69 \pm 0.33^{\mathrm{d}}$ & $33.39 \pm 2.25^{\mathrm{c}}$ & $12.95 \pm 0.15^{\mathrm{c}}$ & $2.29 \pm 0.04^{\mathrm{a}}$ \\
& Phichit 65-3 & $3.08 \pm 0.01^{\mathrm{a}}$ & $3.93 \pm 0.12^{\mathrm{a}}$ & $2.80 \pm 0.12^{\mathrm{a}}$ & $8.21 \pm 0.07^{\mathrm{bc}}$ & $32.69 \pm 0.51^{\mathrm{c}}$ & $12.07 \pm 0.12^{\mathrm{b}}$ & $2.55 \pm 0.04^{\mathrm{a}}$ \\
& Phichit 290-9 & $3.23 \pm 0.10^{\mathrm{a}}$ & $3.83 \pm 0.10^{\mathrm{a}}$ & $2.66 \pm 0.11^{\mathrm{a}}$ & $8.46 \pm 0.25^{\mathrm{cd}}$ & $25.06 \pm 0.31^{\mathrm{a}}$ & $10.87 \pm 0.07^{\mathrm{a}}$ & $2.43 \pm 0.17^{\mathrm{a}}$ \\
& Torperk & $3.19 \pm 0.09^{\mathrm{a}}$ & $3.66 \pm 0.10^{\mathrm{a}}$ & $2.45 \pm 0.01^{\mathrm{a}}$ & $8.18 \pm 0.10^{\mathrm{bc}}$ & $33.45 \pm 0.33^{\mathrm{c}}$ & $12.19 \pm 0.07^{\mathrm{b}}$ & $2.25 \pm 0.05^{\mathrm{a}}$ \\
\hline Pre-Gelatinized & Maejo 343 & $7.03 \pm 0.25^{\mathrm{c}}$ & $6.04 \pm 0.15^{\mathrm{b}}$ & $4.87 \pm 0.02^{\mathrm{b}}$ & $6.45 \pm 0.11^{\mathrm{a}}$ & $40.82 \pm 0.23^{\mathrm{d}}$ & $10.89 \pm 0.13^{\mathrm{a}}$ & $2.19 \pm 0.06^{\mathrm{a}}$ \\
& Phichit 65-3 & $6.49 \pm 0.13^{\mathrm{b}}$ & $7.00 \pm 0.21^{\mathrm{c}}$ & $5.70 \pm 0.27^{\mathrm{c}}$ & $6.45 \pm 0.00^{\mathrm{a}}$ & $41.80 \pm 1.17^{\mathrm{d}}$ & $11.53 \pm 0.75^{\mathrm{ab}}$ & $2.34 \pm 0.14^{\mathrm{a}}$ \\
& Phichit 290-9 & $6.46 \pm 0.06^{\mathrm{b}}$ & $6.06 \pm 0.05^{\mathrm{b}}$ & $5.04 \pm 0.07^{\mathrm{b}}$ & $7.84 \pm 0.05^{\mathrm{b}}$ & $27.89 \pm 0.06^{\mathrm{b}}$ & $11.08 \pm 0.03^{\mathrm{a}}$ & $2.60 \pm 0.48^{\mathrm{a}}$ \\
& Torperk & $6.85 \pm 0.04^{\mathrm{c}}$ & $7.50 \pm 0.15^{\mathrm{d}}$ & $6.35 \pm 0.19^{\mathrm{d}}$ & $6.82 \pm 0.14^{\mathrm{a}}$ & $42.75 \pm 0.83^{\mathrm{d}}$ & $11.96 \pm 0.27^{\mathrm{b}}$ & $2.53 \pm 0.04^{\mathrm{a}}$ \\
\hline
\end{tabular}

Note. Each value represents mean values \pm standard error.

WBC: Water Binding Capacity, WHC: Water Holding Capacity, SV: Swelling Volume, WAI: Water Absorption Index, WSI: Water Solubility Index, SP: Swelling Power, OAC: Oil Absorption Capacity.

${ }^{\text {a-h }}$ Mean values within the same column with different letters are significantly different at $p<0.05$. 
Pasting properties of Thai purple sweet potato flours were determined by a Rapid Visco Analyzer (RVA) (Table 3). Sweet potato varieties and flour preparation both significantly affected the pasting properties $(\mathrm{p}<0.05)$. Pasting temperature (PT) was only observed in native Phichit 65-3, Maejo 343 and 290-9 flours (83.32, 85.02 and $86.53{ }^{\circ} \mathrm{C}$, respectively). Results indicated that starch granules of Torperk and pre-gelatinized flours swell more rapidly beyond the gelatinization temperature. Phichit 290-9 flours exhibited the highest values of final viscosity and set back, indicating the starch granule had high capacity to form gel with high retrogradation tendency. Breakdown reflects the shear stability of hot paste, all pre-gelatinized flours presented lower breakdown viscosity than native flour. Differences in breakdown have been related to disparate rigidities of swollen granules. Pre-gelatinized Torperk flours showed the lowest breakdown (1.17 RVU) and setback (8.11 RVU), indicating the high sensitivity to thermal processing and the low rate of retrogradation. Viscosity profiles of Maejo 343 and Phichit 65-3 flours showed more similar patterns than other varieties. Peak time ranged between 4.13 and $6.98 \mathrm{~min}$. The short peak time supported that all Thai purple sweet potato flours were easy to cook. Different pasting properties might be due to the genetic factor, the accumulation of starch granules and their structural properties (Aina et al., 2009; Soison et al., 2014).

Table 3. Pasting properties of purple sweet potato flours

\begin{tabular}{lllllll}
\hline \multirow{2}{*}{ Flour } & \multirow{2}{*}{ Variety } & \multicolumn{5}{c}{ Viscosity (RVU) } \\
\cline { 3 - 6 } & & Peak & Trough & Breakdown & Final & Setback \\
\hline Native & Maejo 343 & $102.03 \pm 1.21^{\mathrm{f}}$ & $55.00 \pm 0.37^{\mathrm{d}}$ & $47.03 \pm 0.89^{\mathrm{e}}$ & $73.69 \pm 0.38^{\mathrm{e}}$ & $18.69 \pm 0.17^{\mathrm{e}}$ \\
& Phichit 65-3 & $86.83 \pm 0.63^{\mathrm{e}}$ & $53.69 \pm 0.49^{\mathrm{d}}$ & $33.14 \pm 0.77^{\mathrm{c}}$ & $70.31 \pm 0.71^{\mathrm{d}}$ & $16.61 \pm 0.26^{\mathrm{d}}$ \\
& Phichit 290-9 & $163.42 \pm 9.31^{\mathrm{g}}$ & $116.67 \pm 8.37^{\mathrm{f}}$ & $46.75 \pm 0.95^{\mathrm{d}}$ & $171.34 \pm 0.47^{\mathrm{g}}$ & $59.67 \pm 1.77^{\mathrm{g}}$ \\
& Torperk & $69.75 \pm 0.14^{\mathrm{d}}$ & $63.22 \pm 0.13^{\mathrm{e}}$ & $6.53 \pm 0.18^{\mathrm{b}}$ & $85.80 \pm 0.50^{\mathrm{f}}$ & $22.58 \pm 0.55^{\mathrm{f}}$ \\
\hline Pre-Gelatinized & Maejo 343 & $24.66 \pm 0.58^{\mathrm{b}}$ & $23.58 \pm 0.65^{\mathrm{c}}$ & $1.08 \pm 0.09^{\mathrm{a}}$ & $34.25 \pm 0.59^{\mathrm{c}}$ & $10.66 \pm 0.14^{\mathrm{b}}$ \\
& Phichit 65-3 & $20.14 \pm 0.13^{\mathrm{a}}$ & $18.75 \pm 0.14^{\mathrm{b}}$ & $1.39 \pm 0.05^{\mathrm{a}}$ & $27.39 \pm 0.10^{\mathrm{b}}$ & $8.64 \pm 0.24^{\mathrm{a}}$ \\
& Phichit 290-9 & $57.83 \pm 0.87^{\mathrm{c}}$ & $57.03 \pm 0.78^{\mathrm{d}}$ & $0.81 \pm 0.13^{\mathrm{a}}$ & $70.00 \pm 0.80^{\mathrm{d}}$ & $12.97 \pm 0.13^{\mathrm{c}}$ \\
& Torperk & $16.28 \pm 0.31^{\mathrm{a}}$ & $15.11 \pm 0.39^{\mathrm{a}}$ & $1.17 \pm 0.09^{\mathrm{a}}$ & $23.22 \pm 0.56^{\mathrm{a}}$ & $8.11 \pm 0.17^{\mathrm{a}}$ \\
\hline
\end{tabular}

Note. Each value represents mean values \pm standard error.

${ }^{\mathrm{a}-\mathrm{g}}$ Mean values within the same column with different letters are significantly different at $p<0.05$.

Antioxidant activity of Thai sweet potato flours is dependent on the phytochemical content and several in vitro mechanisms. Total phenolic content (TPC) and total anthocyanin content (TAC) were measured (Table 4). TPC and TAC values ranged between 22.7-226.9 $\mathrm{mg} \mathrm{GAE} / 100 \mathrm{~g} \mathrm{db}$ and 10.3-182.8 $\mathrm{mg} / 100 \mathrm{~g} \mathrm{db}$, respectively. TPC and TAC values of flours differed between varieties and increased in pre-gelatinized flours. The pre-gelatinized 290-9 flour showed the higher TPC at almost 10 times than native. Among the pre-gelatinized flours, Phichit 65-3 showed the highest TPC and TAC values, while Torperk presented the lowest values. In this study, Torperk flours recorded lower TPC and TAC values than previously reported (Soison et al., 2014) which might be related to the cultivation area, growing conditions and environment of Torperk root production. High TPC and low TAC were found in both Phichit 290-9 and Torperk varieties. Results suggested that anthocyanin quantities as the large group of phenolic compounds in purple sweet potatoes varied depending on the cultivar. 
Table 4. Antioxidant activity of purple sweet potato flours

\begin{tabular}{lllllll}
\hline Flour & Variety & $\begin{array}{l}\text { TPC } \\
(\mathrm{mg} \mathrm{GAE} / \mathrm{g} \mathrm{db})\end{array}$ & $\begin{array}{l}\text { TAC } \\
(\mathrm{mg} / \mathrm{g} \mathrm{db})\end{array}$ & $\begin{array}{l}\text { DPPH } \\
(\mathrm{mg} \mathrm{TE} / \mathrm{g} \mathrm{db})\end{array}$ & $\begin{array}{l}\text { TEAC } \\
(\mathrm{mg} \mathrm{TE} / \mathrm{g} \mathrm{db})\end{array}$ & $\begin{array}{l}\text { FRAP } \\
(\mathrm{mg} \mathrm{TE} / \mathrm{g} \mathrm{db})\end{array}$ \\
\hline Native & Maejo 343 & $0.393 \pm 0.014^{\mathrm{b}}$ & $0.378 \pm 0.008^{\mathrm{b}}$ & $0.779 \pm 0.012^{\mathrm{a}}$ & $8.987 \pm 0.244^{\mathrm{b}}$ & $2.001 \pm 0.066^{\mathrm{b}}$ \\
& Phichit 65-3 & $0.697 \pm 0.042^{\mathrm{c}}$ & $0.678 \pm 0.052^{\mathrm{c}}$ & $2.162 \pm 0.015^{\mathrm{ab}}$ & $18.03 .2 \pm 0.566^{\mathrm{c}}$ & $3.768 \pm 0.092^{\mathrm{c}}$ \\
& Phichit 290-9 & $0.227 \pm 0.007^{\mathrm{a}}$ & $0.163 \pm 0.008^{\mathrm{a}}$ & $0.556 \pm 0.051^{\mathrm{a}}$ & $4.966 \pm 0.136^{\mathrm{a}}$ & $1.150 \pm 0.036^{\mathrm{a}}$ \\
& Torperk & $0.399 \pm 0.009^{\mathrm{b}}$ & $0.103 \pm 0.002^{\mathrm{a}}$ & $1.356 \pm 0.084^{\mathrm{a}}$ & $10.239 \pm 0.070^{\mathrm{b}}$ & $2.240 \pm 0.052^{\mathrm{b}}$ \\
Pre-Gelatinized & Maejo 343 & $0.877 \pm 0.041^{\mathrm{d}}$ & $0.829 \pm 0.034^{\mathrm{e}}$ & $3.264 \pm 0.081^{\mathrm{c}}$ & $25.729 \pm 0.338^{\mathrm{d}}$ & $5.629 \pm 0.088^{\mathrm{d}}$ \\
& Phichit 65-3 & $1.797 \pm 0.049^{\mathrm{f}}$ & $1.828 \pm 0.025^{\mathrm{f}}$ & $6.630 \pm 0.093^{\mathrm{c}}$ & $62.765 \pm 1.363^{\mathrm{g}}$ & $10.936 \pm 0.092^{\mathrm{f}}$ \\
& Phichit 290-9 & $2.269 \pm 0.72^{\mathrm{g}}$ & $0.602 \pm 0.030^{\mathrm{d}}$ & $9.094 \pm 0.043^{\mathrm{c}}$ & $74.836 \pm 2685^{\mathrm{f}}$ & $14.847 \pm 0.098^{\mathrm{g}}$ \\
& Torperk & $1.101 \pm 0.95^{\mathrm{e}}$ & $0.478 \pm 0.042^{\mathrm{c}}$ & $4.128 \pm 0.199^{\mathrm{b}}$ & $38.391 \pm 1.117^{\mathrm{e}}$ & $7.129 \pm 0.099^{\mathrm{e}}$ \\
\hline
\end{tabular}

Note. Each value represents mean values \pm standard error.

TPC: Total Phenolic Content, TAC: Total Anthocyanin Content, DPPH: DPPH free radical scavenging activity, TEAC: Trolox equivalent antioxidant capacity, FRAP: Ferric-reducing antioxidant power.

${ }^{\mathrm{a}-\mathrm{g}}$ Mean values within the same column with different letters are significantly different at $p<0.05$.

Here, well-known in vitro methods such as DPPH, TEAC and FRAP assays were used to measure antioxidant activities of Thai purple sweet potato flours. DPPH and TEAC assays determined the free radical scavenging capacity in different conditions while FRAP assays assessed the chelating metal ion. Antioxidant activity differed depending on the sweet potato variety and preparation method. An increase in antioxidant activity of pre-gelatinized flours was observed in all analyses. DPPH and TEAC values ranged between 0.556-9.094 mg $\mathrm{TE} / \mathrm{g} \mathrm{db}$ and 4.966-74.836 mg TE/g db, respectively. Different flour preparation directly affected DPPH and TEAC values of Phichit 290-9 flours; native flour had the lowest values while pre-gelatinized flour showed the highest. The FRAP assays followed the same trend as DPPH and TEAC assays. All flours had FRAP values ranging between 1.150-14.847 mg TE/g db with pre-gelatinized Phichit 290-9 flour giving the highest FRAP values. The Phichit 65-3 variety showed high levels of anthocyanins and antioxidant activity for both native and pre-gelatinized flours, while pre-gelatinized Phichit 290-9 flour had the highest phenolic content and antioxidant activity.

Changes in the phenolic compounds after thermal processing related to the loss of heat-sensitive constituents. Degradation of phenolic compounds occurs through enzyme activity as a result of thermal processing. Degradation rate of phenolic compounds depends on many factors including the number of substituents, the molecular structure and the accumulation of phenolic compounds in the plant. However, an increase in phenolic compounds after thermal processing was reported by several authors as the degraded polyphenols resulted in free and smaller molecules with easy extraction of constituents (Huang et al., 2006; Tokusoglu \& Yildirim, 2012). Many studies reported that thermal treatment enhanced anthocyanins content in several purple sweet potato varieties including Stokes purple, NC415, Okinawa, Phichit 65-3 and Torperk (Truong et al., 2010; Soison et al., 2014; Ruttarattanamongkol et al., 2016). Phenolic compounds and anthocyanins in purple sweet potatoes show powerful antioxidant activity. The main anthocyanins in purple sweet potatoes are 3,5-diglucoside derivatives from cyanidin and peonidin, acylated with p-hydroxybenzoic acid, ferulic acid, or caffeic acid, respectively (Kim et al., 2012). High concentrations of anthocyanins were observed in Phichit 65-3 and Maejo 343 flours. Their pre-gelatinized flours also showed strong antioxidant activity which might be due to higher amounts of acylated anthocyanidins which are more stable during processing and storage. Acylation of anthocyanin improves its stability through intermolecular co-pigmentation (Giustri \& Wrolstad, 2003; Cevallos-casals \& Cisneros-Zevallos, 2004). The high antioxidant activity of Phichit 290-9 and Torperk flours related to their high phenolic compounds. Results also confirmed that Thai purple sweet potatoes are good sources of natural antioxidant constituents and very stable under thermal processing. Flours produced from Thai purple sweet potatoes show potential as good sources of natural colorants, and dietary phytochemicals and antioxidants. Moreover, steam pre-treatment enhanced the deep purple color and improved the pasting properties of Thai sweet potato flours as beneficial for use in food products.

\subsection{Physical Properties of Air-Puffed Purple Sweet Potato Snacks}

From results in 3.1, native and pre-gelatinized flours produced from Phichit 65-3 variety showed good characteristics for color, pasting properties, high anthocyanin and antioxidant activity. Thus, Phichit 65-3 flours were used for purple sweet potato snack production. Figure 3 presents air-puffed purple sweet potato snacks with 
different ratios of pre-gelatinized flours at 10\%, 30\% and 50\% (G10, G30 and G50), respectively. Snacks made from sweet potato flours showed better shape and size than control but a deep purple color was presented in control and G50. Formulation of snacks using sweet potato flours can be increased and expanded depending on the content of pre-gelatinized flours (Table 5). The G10 showed the highest expansion ratio followed by G50 (6.65 and 4.41, respectively) while control snack had the lowest values (2.49). Low bulk density relates to high expansion, G10 and G50 showed the lowest bulk density ( 0.276 and 0.277 , respectively). Changing expansion of snacks depended on raw materials, amylose-amylopectin ratio, the amount of native starch and degree of gelatinization (Norton et al., 2011; Wang et al., 2012; Jiamjariyatam et al., 2017). This result supported that the ratio of native and pre-gelatinized sweet potato flours was important to improve expansion properties of air-puffed snacks.

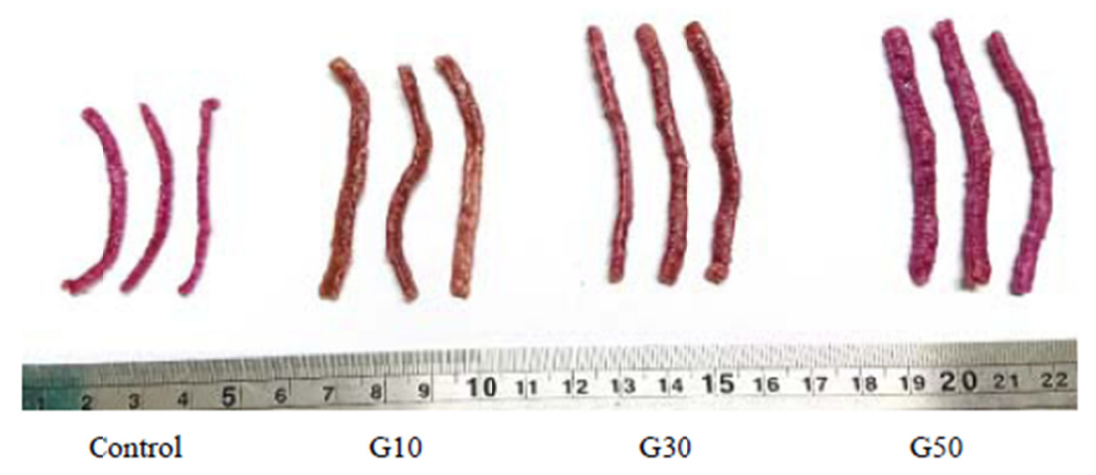

Figure 3. Appearance of air-puffed Thai purple sweet potato snacks

Color of snacks showed significant difference in redness and blueness values $(p<0.05)$. Increasing the content of pre-gelatinized flour increased the $a^{*}$ and $-b^{*}$ values of snacks. Maximum values of $a^{*}$ and $-b^{*}$ were observed in G50 prepared by maximum content of pre-gelatinized flour. Native flours showed lower redness than pre-gelatinized flour; thus, decreasing the content of pre-gelatinized flour in G10 and G30 directly affected the low $a^{*}$ value of snacks. Conversely, control snacks showed higher $a^{*}$ and $-b^{*}$ values than G10 and G30, supporting the notion that steamed pre-treatment played an important role in heat stable pigment formation. Purple sweet potato snacks obtained by G50 had good appearance with deep intense purple color, high expansion ratio and low bulk density.

Table 5. Expansion and color of purple sweet potato snacks

\begin{tabular}{|c|c|c|c|c|c|}
\hline \multirow{2}{*}{ Sample } & \multirow{2}{*}{ Expansion ratio } & \multirow{2}{*}{$\begin{array}{l}\text { Bulk density } \\
\left(\mathrm{g} / \mathrm{cm}^{3}\right)\end{array}$} & \multicolumn{3}{|c|}{ Color value } \\
\hline & & & $L^{*}$ & $a^{*}$ & $b^{*}$ \\
\hline Control & $2.49 \pm 0.20^{\mathrm{a}}$ & $0.470 \pm 0.009^{\mathrm{c}}$ & $44.82 \pm 3.01^{\mathrm{b}}$ & $19.52 \pm 0.84^{\mathrm{c}}$ & $0.96 \pm 0.13^{b}$ \\
\hline G10 & $6.65 \pm 1.11^{\mathrm{c}}$ & $0.276 \pm 0.011^{\mathrm{a}}$ & $43.57 \pm 2.01^{\mathrm{ab}}$ & $10.25 \pm 0.82^{\mathrm{a}}$ & $6.47 \pm 0.63^{\mathrm{d}}$ \\
\hline G30 & $3.11 \pm 0.55^{\mathrm{ab}}$ & $0.389 \pm 0.011^{\mathrm{b}}$ & $40.00 \pm 2.65^{\mathrm{a}}$ & $12.54 \pm 1.03^{\mathrm{b}}$ & $3.70 \pm 0.28^{\mathrm{c}}$ \\
\hline G50 & $4.41 \pm 0.38^{\mathrm{b}}$ & $0.277 \pm 0.014^{\mathrm{a}}$ & $44.65 \pm 3.01^{\mathrm{b}}$ & $19.39 \pm 0.69^{\mathrm{c}}$ & $-2.67 \pm 0.29^{a}$ \\
\hline
\end{tabular}

Note. Each value represents mean values \pm standard error.

Color values: $L^{*}, a^{*}$ and $b^{*}$ mean lightness, redness and yellowness, respectively.

a-d Mean values within the same column with different letters are significantly different at $p<0.05$.

Macrostructures of purple sweet potato snacks were determined using SEM as shown in Figure 4. There was obvious difference between the structures of each air-puffed snack. Thickening of cell wall, rigid structure and fewer air cells mainly affected the lowest expansion of control snack. G10 had a more homogeneous network with smaller pore size. The uniform air cell distribution and size also found in G10. Occurrence of highly small porous structures with thin cell walls in G10 might support the highest expansion recorded in our results. Large expanded bubbles presented in G30 and G50 were prepared by high content of pre-gelatinized flours. G30 found many visible empty holes in the structure and larger air cells with various size and shape was observed. G50 
presented a homogeneous network, thinner cell wall and large air cells. From the results, both G10 and G50 showed high expansion with different macrostructure. Native flour was the main ingredients of G10 causing the network of many small air cells while pre-gelatinized flours in G50 presented as highly porous with large pore-size. In contrast, steamed sweet potato used in control snacks gave dense structure and low expansion. The ratio between native and pre-gelatinized flours was a key factor to develop physical structure of purple sweet potato snacks.

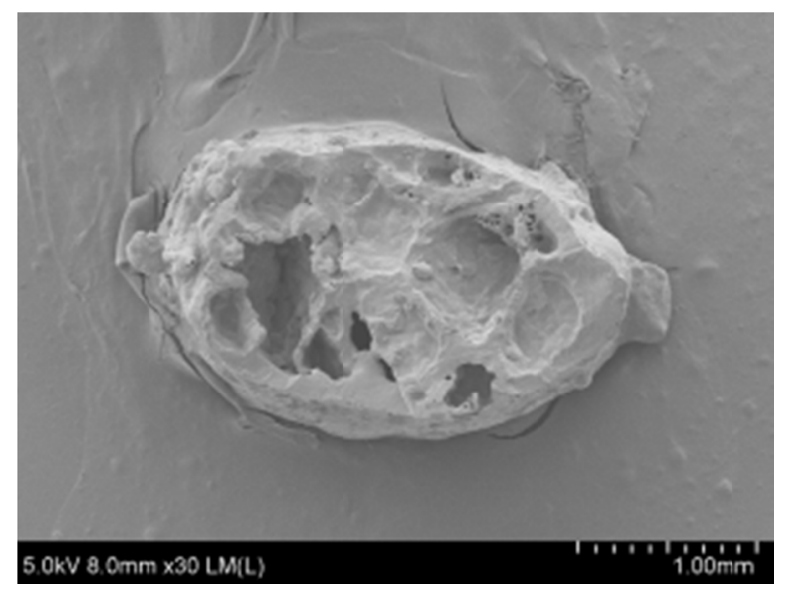

Control

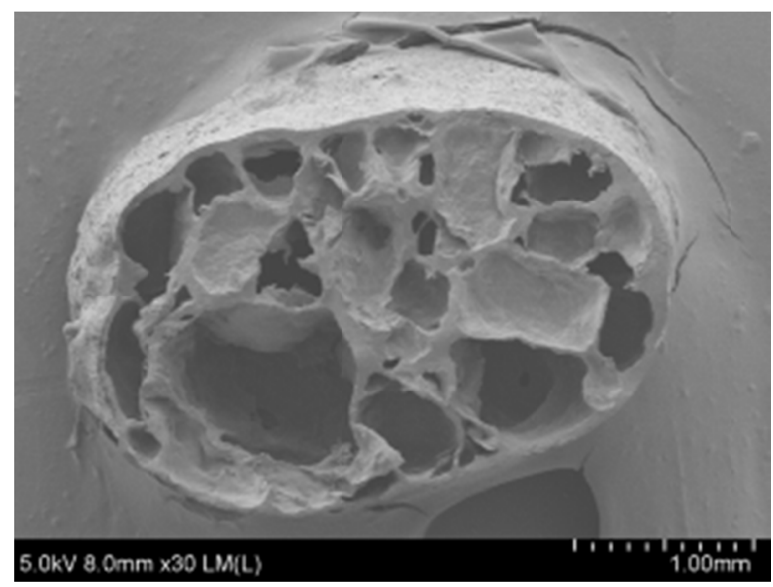

G30

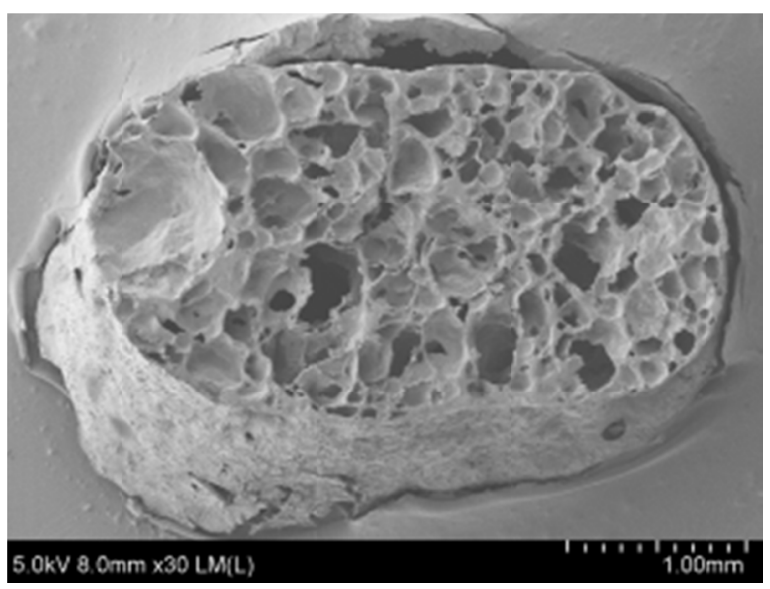

G10

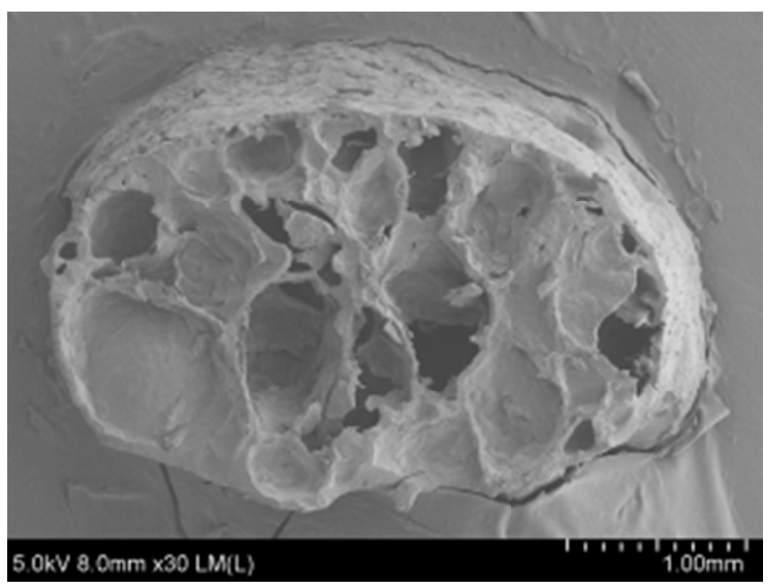

G50

Figure 4. SEM image of air-puffed purple sweet potato snacks

Results of hardness and crispiness measured by texture analyzer were presented in Figure 5 and control snack showed higher hardness than others significantly $(\mathrm{p}<0.05)$. Highest hardness of control snack might be involved with low expansion, especially the dense structure and thickening cell wall confirmed with SEM image. There was no significant difference $(\mathrm{p}<0.05)$ in hardness when increasing the content of pre-gelatinized sweet potato flour $(10 \%, 30 \%$ and $50 \%)$. Decreasing hardness related to high expansion of all snacks formulated by sweet potato flour. Crispiness of snacks ranged between 94.41 and $115.64 \mathrm{~kg}$. sec. Lowest crispiness was found in G50, while control snacks showed highest values. Pre-gelatinized flour content was considered for texture modification of air-puffed sweet potato snacks because of their expansion. Colored potato flour can be used as a component of fried snacks to improve their texture and expansion ratio dependent on the content of gelatinized starch (Nemś et al., 2015). 

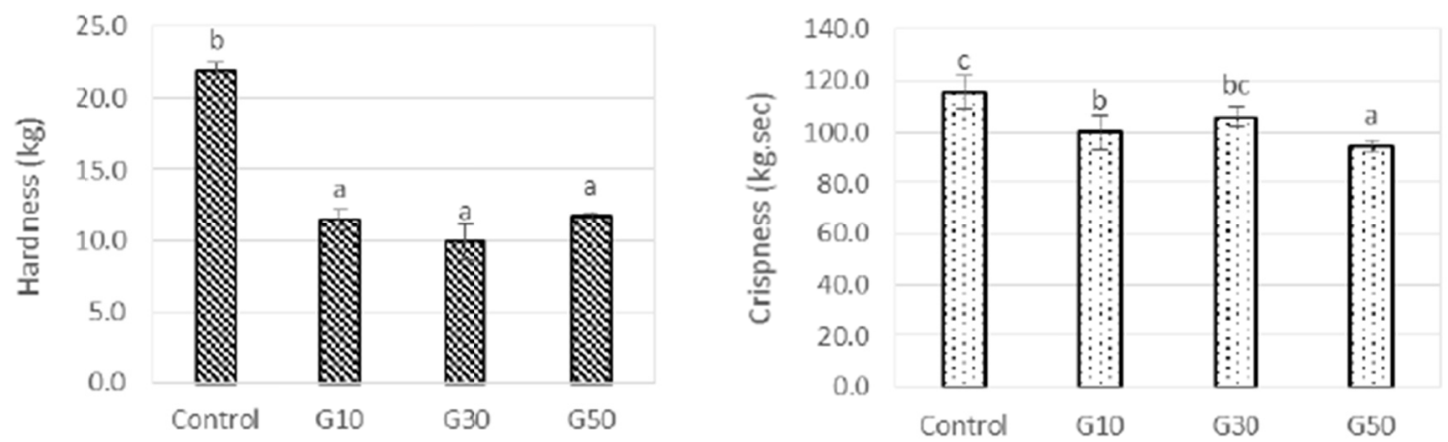

Figure 5. Texture of purple sweet potato snacks (A) hardness and (B) Crispiness

Note. ${ }^{\text {a-c }}$ Mean values with different letters are significantly different at $p<0.05$.

Total phenolic and anthocyanin content of snacks increased significantly $(p<0.05)$ when content of pre-gelatinized flour increased. G50 had the highest values following by control snack and G30. Steamed sweet potato and pre-gelatinized flour showed high content of heat stable phenolic and anthocyanin. While the native flour showed 3 times lower anthocyanin content than pre-gelatinized flour, thus G10 formulated with high native flour had the lowest TAC values $(0.046 \mathrm{mg} / \mathrm{g})$. Antioxidant activity of snacks showed the same trend of total phenolic content and total anthocyanin content. G50 showed the highest values of DPPH, TEAC and FRAP while G10 showed the lowest in all assays. However, control snacks prepared by steamed sweet potato showed similar antioxidant activity with snacks prepared by $50 \%$ pre-gelatinized flour (G50). Results of air-puffed snacks also confirmed that phytochemicals in steamed sweet potato and pre-gelatinized flours were heat stable compounds, while native flours were heat sensitive. According to Nemś et al. (2015), total phenolic content and antioxidant activity of snacks enriched with colored potato flour depended on variety, quantity and profiles of these compounds in raw material.

Table 6. Antioxidant activity of purple sweet potato snacks

\begin{tabular}{llllll}
\hline Sample & $\begin{array}{l}\text { TPC } \\
(\mathrm{mg} \mathrm{GAE} / \mathrm{g} \mathrm{db})\end{array}$ & $\begin{array}{l}\text { TAC } \\
(\mathrm{mg} / \mathrm{g} \mathrm{db})\end{array}$ & $\begin{array}{l}\text { DPPH } \\
(\mathrm{mg} \mathrm{TE} / \mathrm{g} \mathrm{db})\end{array}$ & $\begin{array}{l}\text { TEAC } \\
(\mathrm{mg} \mathrm{TE} / \mathrm{g} \mathrm{db})\end{array}$ & $\begin{array}{l}\text { FRAP } \\
(\mathrm{mg} \mathrm{TE} / \mathrm{g} \mathrm{db})\end{array}$ \\
\hline Control & $1.877 \pm 0.060^{\mathrm{c}}$ & $0.495 \pm 0.037^{\mathrm{c}}$ & $3.095 \pm 0.029^{\mathrm{c}}$ & $4.671 \pm 0.109^{\mathrm{c}}$ & $0.904 \pm 0.29^{\mathrm{c}}$ \\
G10 & $0.860 \pm 0.059^{\mathrm{a}}$ & $0.046 \pm 0.006^{\mathrm{a}}$ & $0.977 \pm 0.032^{\mathrm{a}}$ & $0.908 \pm 0.013^{\mathrm{a}}$ & $0.269 \pm 0.008^{\mathrm{a}}$ \\
G30 & $1.214 \pm 0.046^{\mathrm{b}}$ & $0.177 \pm 0.026^{\mathrm{b}}$ & $1.606 \pm 0.057^{\mathrm{b}}$ & $2.175 \pm 0.034^{\mathrm{b}}$ & $0.427 \pm 0.005^{\mathrm{b}}$ \\
G50 & $2.222 \pm 0.057^{\mathrm{d}}$ & $0.549 \pm 0.013^{\mathrm{d}}$ & $4.144 \pm 0.068^{\mathrm{d}}$ & $5.701 \pm .108^{\mathrm{d}}$ & $1.079 \pm 0.022^{\mathrm{d}}$ \\
\hline
\end{tabular}

Note. Each value represents mean values \pm standard error.

TPC: Total Phenolic Content, TAC: Total Anthocyanin Content, DPPH: DPPH free radical scavenging activity, TEAC: Trolox equivalent antioxidant capacity, FRAP: Ferric-reducing antioxidant power.

${ }^{\text {a-d }}$ Mean values within the same column with different letters are significantly different at $p<0.05$.

\section{Conclusion}

Different varieties of Thai purple sweet potatoes flours showed unique attributes in terms of color, pasting properties and antioxidant activity. Native flours maintained pasting properties compared to pre-gelatinized flours. Pre-gelatinized flours showed color improvement with increasing TPC, TAC and antioxidant activity. Phichit 65-3 flours showed a deep intense purple color with high anthocyanin content, antioxidant activity and good pasting properties. Application of purple sweet potato flours in air-puffed snacks improved the appearance, expansion ratio, physical structure and texture. Combination of native and pre-gelatinized flour directly affected the color and antioxidant activity. Purple sweet potato snacks prepared by pre-gelatinized flour $50 \%$ (G50) had unique purple color with good appearance and texture. They were also a good source of phenolic compounds, anthocyanins and antioxidant activity. Thai purple sweet potato flours showed promising potential application in healthy snack products with antioxidant enrichment and natural colorants. This knowledge can support the commercialization of purple sweet potato flour in health food products and for other specific purposes. 


\section{Acknowledgements}

The authors would like to acknowledge the financial assistance provided by the Kasetsart University Research and Development Institute and the Institute of Food Research and Product Development, Kasetsart University, Thailand. They also extend their thanks to Phichit Agriculture Development and Research Center, Phichit, Thailand for the supply of four purple sweet potato varieties.

\section{References}

Aina, A. J., Falade, K. O., Akingbala, J. O., \& Titus, P. (2009). Physicochemical properties of twenty-one Caribbean sweet potato cultivars. International Journal of Food Science Technology, 44, 1696-1704. https://doi.org/10.1111/j.1365-2621.2009.01941.x

AOAC. (2000). Official Methods of Analysis (17th ed.). Association of Official Analytical Chemists, Virginia.

Benzie, I. F. F., \& Strain, J. J. (1999). Ferric reducing/antioxidant power assay: direct measure of total antioxidant activity of biological fluids and modified version of simultaneous measurement of total antioxidant power and ascorbic acid concentration. Methods in Enzymology, 299, 15-27. https://doi.org/ 10.1016/s0076-6879(99)99005-5

Brand-Williams, W., Cuvelier, M. E., \& Berset, C. (1995). Use of a free radical method to evaluate antioxidant activity. Lebensmittel-Wissenschaft and Technologie, 28, 25-30. https://doi.org/10.1016/s0023-6438(95)800 $08-5$

Bridgers, E. N., Chinn, M. S., \& Truong, V.-D. (2010). Extraction of anthocyanins from industrial purple-fleshed sweetpotatoes and enzymatic hydrolysis of residues for fermentable sugars. Industrial Crops and Products, 32, 613-620. https://doi.org/10.1016/j.indcrop.2010.07.020

Cevallos-Casals, B. A., \& Cisneros-Zevallos, L. (2004). Stability of anthocyanin-based aqueous extracts of Andean purple corn and red-fleshed sweet potato compared to synthetic and natural colorants. Food Chemistry, 86(1), 69-77. https://doi.org/10.1016/j.foodchem.2003.08.011

Cornejo, F., \& Rosell, C. M. (2015). Physicochemical properties of long rice grain varieties in relation to gluten free bread quality. LWT-Food Science and Technology, 62, 1203-1210. https://doi.org/10.1016/j.lwt. 2015.01.050

Fiorda, F. A., Soares, M. S., da Silva, F. A., de Moura, C. M. A., \& Grossmann, M. V. E. (2015). Physical quality of snacks and technological properties of pre-gelatinized flours formulated with cassava starch and dehydrated cassava bagasse as a function of extrusion variables. LWT-Food Science and Technology, 62, 1112-1119. https://doi.org/10.1016/j.lwt.2015.02.030

Giustri, M. M., \& Wrolstad, R.E. (2003). Acylated anthocyanins from edible sources and their applications in food systems. Biochemical Engineering Journal, 42, 29-43. https://doi.org/10.1016/s1369-703x(02)00 221-8

Gunaratne, A., \& Hoover, R. (2002). Effect of heat-moisture treatment on the structure and physicochemical properties of tuber and root starches. Carbohydrate Polymers, 49, 425-437. https://doi.org/10.1016/ s0144-8617(01)00354-x

Huang, Y. C., Chang, Y. H., \& Shao, Y. Y. (2006). Effects of genotype and treatment on the antioxidant activity of sweet potato in Taiwan. Food Chemistry, 98, 529-538. https://doi.org/10.1016/j.foodchem.2005.05.083

Jiamjariyatam, R. (2017). Microwavable expanded-snack from native rice starch: Influence of inulin and amylose content. International Food Research Journal, 24(5), 1956-1962.

Reddy, M. K., Kuna, A., Lakshmi, Devi, N. L., Krishnaiah, N., Kaur, C., \& Nagamalleswari, Y. (2014). Development of extruded Ready-To-Eat (RTE) snacks using corn, black gram, roots and tuber flour blends. Journal of Food Science and Technology, 51(9), 1929-1937. https://doi.org/10.1007/s13197-013-1251-0

Mariotti M., Alamprese C., Pagani M. A., \& Lucisano M. (2006). Effect of puffing on ultrastructure and physical characteristics of cereal grains and flours. Journal of Cereal Science, 43(1), 47-56. https://doi.org/10.1016/ j.jcs.2005.06.007

Moorthy, S. N., Sajeev, M., \& Shanavas, S. (2012). Sweet potato Starch: Physico-chemical, functional, thermal and rheological characteristics. Fruit, Vegetable and Cereal Science and Biotechnology, 6, 124-133. 
Nath, A., \& Chattopadhyay, P. K. (2007). Optimization of oven toasting for improving crispness and other quality attributes of ready to eat potato-soy snack using response surface methodology. Journal of Food Engineering, 80(4), 1282-1292. https://doi.org/10.1016/j.jfoodeng.2006.09.023

Neelam, K., Vijay, S., \& Lalit, S. (2012). Various techniques for the modification of starch and the applications of its derivatives. International Research Journal of Pharmacy, 3(5), 25-31.

Nems, A., Peksa, A., Kucharska, A. Z., Towska, A. S.-Ł., Kita, A., Drozdz, W., \& Hamouz, K. (2015). Anthocyanin and antioxidant activity of snacks with coloured potato. Food Chemistry, 172, 175-182. https://doi.org/10.1016/j.foodchem.2014.09.033

Norton, A. D., Greenwood, R. W., Noble, I., \& Cox, P. W. (2011). Hot air expansion of potato starch pellets with different water contents and salt concentrations. Journal of Food Engineering, 105, 119-127. https://doi.org/ 10.1016/j.jfoodeng.2011.02.014

Oki, T., Masuda, M., Furuta, S., Nishiba, Y., Terahara, N., \& Suda, I. (2002). Involvement of anthocyanins and other phenolic compounds in radical-scavenging activity of purple-fleshed sweet potato cultivars. Journal of Food Science, 67, 1752-1756. https://doi.org/10.1111/j.1365-2621.2002.tb08718.x

Ramesh Yadev, A., Guha, M., Tharanathan, R. N., \& Ramteke, R. S. (2006). Changes in characteristics of sweet potato flour prepared by different drying techniques. LWT-Food Science and Technology, 39, 20-26. https://doi.org/10.1016/j.lwt.2004.12.010

Reugmaneepaitoon, S. (2009). Development of instant fried noodles made from composite flour of wheat and sweet potato flours. Kasetsart Journal: Natural Science, 43, 768-779.

Ruttarattanamongkol, K., Chittrakorn, S, Weerawatanakorn, M., \& Dangpium, N. (2016). Effect of drying conditions on the properties, pigments and antioxidant activity retention of pretreated orange and purple-fleshed sweet potato flours. Journal of Food Science Technology, 53(4), 1811-1822. https://doi.org/ 10.1007/s13197-015-2086-7

Sahin, S. A. S. (2006). Physical properties of foods. Springer publications (pp. 1-36). United States of America.

Segnini, S., Pedreschi, F., \& Dejmek, P. (2004). Volume measurement method of potato chips. International Journal of Food Properties, 1(1), 37-44. https://doi.org/10.1081/jfp-120022494

Singleton, V. L., Orthofer, R., \& Lamuela-Raventos, R. M. (1999). Analysis of total phenol and other oxidation substrates and antioxidants by mean of Folin-Ciocalteu Reagent. Methods in Enzymology, 299, 152-177. https://doi.org/10.1016/s0076-6879(99)99017-1

Soison, B., Jangchud, K., Jangchud, A., Harnsilawat, T., Piyachomkwan, K., Charunuch, C., \& Prinyawiwatkul, W. (2014). Physico-functional and antioxidant properties of purple-flesh sweet potato flours as affected extrusion and drum-drying treatments. International Journal of Food Science and Technology, 49, 2067-2075. https://doi.org/10.1111/ijfs.12515

Suda, I., Oki, T., Masuda, M., Kobayashi, M., Nishiba, Y., \& Furuta, S. (2003). Physiological functionality of purple-fleshed sweet potatoes containing anthocyanins and their utilization in foods. Japan Agricultural Research Quarterly, 37, 167-173. https://doi.org/10.6090/jarq.37.167

Tai-Yuan, C., Hsuan-Min, L., Pang-Hung, H., \& Sung, W.-C. (2016). Effects of calcium supplements on the quality and acrylamide content of puffed shrimp chips. Journal of Food and Drug Analysis, 24(1), 164-172. https://doi.org/10.1016/j.jfda.2015.05.007

Teow, C. C., Truong, V.-D., McFeeters, R. F., Thompson, R. L., Pecota, K. V., \& Yencho, G. C. (2007). Antioxidant activities, phenolic and $\beta$-carotene contents of sweet potato genotypes with varying flesh colours. Food Chemistry, 50, 1672-1676. https://doi.org/10.1016/j.foodchem.2006.09.033

Terahare, N., Konczak, I., Ono, H., Yoshimoto, M., \& Yamakawa, O. (2004). Characterization of Acylated Anthocyanins in Callus Induced From Storage Root of Purple-Fleshed Sweet Potato, Ipomoea batatas L. Journal of Biomedicine and Biotechnology, 5, 279-286. https://doi.org/10.1155/s1110724304406056

Tokusoglu, O., \& Yildirim, Z. (2012). Effects of cooking methods on the anthocyanin levels and antioxidant activity of local Turkish sweetpotato [Ipomamas batats (L.)] cutivar Hatay kirmizi: boiling, steaming and frying effects. Turkish Journal of Field Crops, 17, 87-90.

Truong, V.-D., Deighton, N., Thompson, R. L., McFeeters, R. F., Dean, L. O., Pecosta, K. V., \& Yencho, G. C. (2010). Characterization of anthocyanins and anthocyanidins in purple-fleshed sweet potatoes by 
HPLC-DAD/ESI-MS/MS. Journal of Agricultural and Food Chemistry, 58, 404-410. https://doi.org/ $10.1021 / \mathrm{jf9} 02799 \mathrm{a}$

Van Hal. (2000). Quality of sweet potato flour during processing and storage. Food Reviews International, 16, 1-37. https://doi.org/10.1021/jf3055455

Wang, Y., Zhang, M. S., \& Mujumdar, A. (2012). Influence of green banana flour substitution for cassava starch on the nutrition, color, texture and sensory quality in two types of snacks. LWT-Food Science and Technology, 47(1), 175-182. https://doi.org/10.1016/j.lwt.2011.12.011

Yang, J., \& Gadi, R. L. (2008). Effects of steaming and dehydration on anthocyanins, antioxidant activity, total phenols and color characteristics of purple-fleshed sweet potatoes (Ipomoea batatas). American Journal of Food Technology, 3, 224-234. https://doi.org/10.3923/ajft.2008.224.234

Zhou, K., \& Yu, L. (2004). Antioxidant properties of bran extracts from Trego wheat grown at different locations. Journal of Agricultural and Food Chemistry, 52, 1112-1117. https://doi.org/10.1021/jf030621m

\section{Copyrights}

Copyright for this article is retained by the author(s), with first publication rights granted to the journal.

This is an open-access article distributed under the terms and conditions of the Creative Commons Attribution license (http://creativecommons.org/licenses/by/4.0/). 